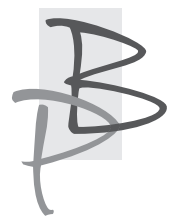

Ludmiła Romaszczenko*

Czerkaski Narodowy Uniwersytet im. B. Chmielnickiego, Ukraina

https://orcid.org/0000-0001-7567-9511

\title{
Иван Франко и Теодор Томаш Еж в контексте проблемы билингвизма
}

В статье рассматривается незаурядный талант Ивана Франко, владеющего многими языками (прежде всего польским), а также его личные и творческие взаимоотношения с Теодором Томашем Ежем. В первую очередь внимание сосредотачивается на демократических устремлениях обоих писателей и расхождениях в оценке украинского освободительного движения, и в то же время на похожих оценках творчества польских художников (в частности Яна Каспровича), на критической рецепции романтизма и польского реализма.

Ключевые слова: польские писатели, украинские писатели, критическая рецепция, романтизм, реализм, билингвизм.

\section{Iwan Franko i Teodor Tomasz Jeż w kontekście problemu dwujęzyczności}

Streszczenie: Badaczka analizuje niezwykły talent Iwana Franki, który władał wieloma językami (przede wszystkim polskim) oraz jego osobiste

Ludmiła Romaszczenko - dr nauk filologicznych, profesor Czerkaskiego Narodowego Uniwersytetu im. B. Chmielnickiego (Ukraina), autorka monografii Жанрово-стильовий розвиток сучасної української історичної прози: Основні напрями художнього руху і ponad 360 artykułów w publikacjach naukowych i literackich Ukrainy, Rosji, Białorusi, Polski, Czech, Niemiec, Rumunii, Litwy, Łotwy, Estonii, Kazachstanu, Azerbejdżanu i innych krajów. 
i literackie stosunki z Teodorem Tomaszem Jeżem. Artykuł skupia się na demokratycznych dążeniach obu działaczy i na kontrowersjach w ocenie ukraińskiego ruchu wyzwoleńczego, na podobnych ocenach twórczości polskich pisarzy (w szczególności Jana Kasprowicza), a także na krytycznej recepcji romantyzmu i polskiego realizmu.

Słowa-klucze: polscy pisarze, ukraińscy pisarze, recepcja krytyczna, romantyzm, realizm, dwujęzyczność

\section{Ivan Franko and Teodor Tomasz Jeż (Zygmunt Miłkowski) in the context of bilingualism}

Summary: The article examines personal and artistic relations between Ivan Franko and Teodor Tomasz Jeż. Special focus is placed upon their aspirations for democracy, as well as on the controversies over assessing the Ukrainian liberation movement - and the fact that Polish writers (e.g. Jan Kasprowicz) held similar views in this respect. The author also touches open critical reception of romanticism and Polish realism.

Key words: Polish, Ukrainian, writer, criticism, democratic, social, romanticism, realism, bilingualism.

В парадигме украинско-польских литературных и общественных взаимоотношений этот человек занимает одно из ведущих мест.

Иван Франко - полиглот, знающий 14 языков, что позволило ему не только переводить, но и самому писать на польском (и немецком) художественные произведения, литературоведческие, исторические, экономические статьи, отзывы на события культурной и научной жизни того времени. А также активно сотрудничать с польскими изданиями. Среди них - двухнедельник, Praca, который выходил во Львове на польском языке. Печатающиеся в нем материалы имели социалистическую направленность, освещали положение рабочих, поддерживали их борьбу за общее избирательное право. Заметное влияние на характер публикаций имел польский социалист Людвиг Тадеуш Варинский (который, кстати, родился в деревне Мартыновке на Черкасчине, а учился в Белоцерков- 
ской гимназии). Со времени вхождения Франко в редакцию часть материалов печаталась на украинском языке (гимн Вечный револючионер и другие литературные произведения). При редакции Франко выдал брошюру Co to jest socjalizm (рус. Что такое социализм), являющую собой изложение экономического учения Карла Маркса, а также Program socjalistów galicyjskich (рус. Программа галицких социалистов, 1881), O pracy: Książeczka dla robotników (рус. О труде: Книжечка для работников, 1881). Praca стала органом Польской социал-демократической партии (1890-1892). Сотрудничал он также с газетой Prawda - еженедельной политической, общественной и литературной газетой, выходившей в Варшаве в 1881-1915 годах, издателем и редактором которой являлся Александр Свентоховский - идеолог вариавского позитивизма. Особенно плодотворным было сотрудничество Франко с газетой демократического направления под названием Kurjer Lwowski, выходившей во Львове ежедневно на протяжении 1883-1935 гг. Например, за десять лет работы в этой газете Франко издал около $800^{1}$ статей разной тематики (по другим источникам - около 900²).

Иван Франко был лично знаком со многими польскими писателями, литературоведами, журналистами, переводчиками, с которыми сотрудничал в польских газетах и журналах, обсуждал актуальные проблемы литературной и общественной жизни, вел оживленную переписку и имел долголетние дружеские отношения. Об этом свидетельствуют польские культурные деятели, сам Франко, а также многочисленный эпистолярий, в котором сохранилось немало писем от Яна Каспровича, Александра Свентоховского, Адама Вислицкого, Болеслава Вислоуха, Стефана Жеромского, Анджея Немоевского, Людвика Кшивицкого, Исидора Коперницкого, братьев Дашинских, Фредро-младшего, Яна Карловича, Юзефы Остои (Савицкой) и др.

Проблему украинско-польских взаимоотношений сквозь призму деятельности Ивана Франко в свое время подробно исследовал Григорий

1 Т. Мартиненко, Публіцистика Івана Франка у дослідженнях Гражини Паздро, [в:] Київські полоністичні студї, редактор Р. Радишевський, т. XXIX, Київ 2017, с. 328.

2 Г. Грабовська, Цикл рещензій на „Галицько-руську бібліографію” І. Левицького на сторінках часопису «Kurjer Lwowski», [в:] Київські полоністичні студіï, редактор Р. Радишевський, т. XXIX, Київ 2017, с. 207. 
Вервес $^{3}$. Однако до сих пор интересной и малоизученной страницей в них остаются творческие отношения Каменяра и польского писателя Теодора Томаша Ежа (1824-1915)4.

Польская исследовательница ХХвека Мария Островская считает Ежа-Милковского одной из наиболее интересных польских личностей XIX века. Этот жолнер и писатель, который, отложив саблю ради дела отчизны, брался за перо ${ }^{5}$ в настоящее время несправедливо подзабытый и малоизвестный. Еще раныше Иван Франко также высоко оценивал его, называл знаменитым романистом, относил к передовым критикам 6 и польским патриотам . А высказывание другого польского исследователя о Еже - политик, общественный деятель, писатель и публицист,

3 См.: Г. Вервес, Іван Франко і питання українсько-польських літературногромадських взаємин, Київ 1957; Г. Вервес, Польська література і Украӥна, Київ 1985.

4 Теодор Томаш Еж - настоящая фамилия Зигмунт Фортунат Милковский родился 23 марта 1824 года на Подолье, в небольшом живописном селе Сарацея. Учился в гимназии в Немирове, но первые его шаги на ниве образования были не совсем успешными: заглядывал в рюмку, влезал в долги и даже разбойничал. На время учебы в Немирове приходятся первые поэтические попытки юноши. Чтобы спасти сына, отец забрал его домой, прервав образование парня. Впоследствии Фортунат поступает на физико- математический факультет Одесского лицея. Закончив его в 22-летнем возрасте, юноша возвращается домой с намерением приготовиться к кандидатскому экзамену в Киевский университет. В 1847 году он изучает здесь курс как свободный слушатель на математическом факультете.

Личность писателя-полковника закалялась в многочисленных битвах за свободу, из-за чего ему было суждено стать изгнанником. Побывал в Молдавии, Болгарии, Сербии, Турции, Венгрии, Англии, до тех пор, пока не поселился на постоянное место жительства в Швейцарии.

Еж оставил достаточно большое литературное наследие - свыше 80 романов, собранных в 40-томном издании, появившемся в 30-х годах XX века. Самым выдающимся среди них является роман Бурное время (1880-1882), состоящий из трех книг. Учитывая исторический фон эпохи и ее главных действующих лиц, изображенных в произведении, роман Ежа рассматривают как предшественника архипроизведения Генрика Сенкевича, один из малоизвестных источников вдохновения автора трилогии Огнем и мечом.

Кроме романа Бурное время, об украинско-польских отношениях Еж написал романы Стародубовское дело (1862) и Отец Никон (1869).

5 M. Ostrowska, T. T. Jeż (Zygmunt Miłkowski). Zycie i twórczość, Kraków 1936, s.2

6 I. Франко, Зібрання творів: У 50 томах, т. 27, Київ 1980, с. 260.

7 І. Франко, Зібрання творів: У 50 томах, т. 50, Київ 1980, с. 84. 
большой демократ и благородный начионалист ${ }^{8}$ - можно применить, характеризуя в том числе и многогранную деятельность Ивана Франко.

Франко и Ежа сближали в первую очередь демократические убеждения. Первый, по существу, возглавил демократическое движение в Галичине, направленное против притеснений польской шляхты и австрийского правительства, за что его потом преследовали. В своей литературной и общественной деятельности Иван Яковлевич сочетал идею социального и национального освобождения.

Исследователи жизни и творчества Ежа также единодушно подчеркивают его демократические убеждения:

неутомимый борец, пионер стремлений к независимости и демократии, что традиции эмиграционной политики внедрял вплоть до XX века и вне границ Польши, стремился постоянно поддерживать очаг борьбы за независимость9.

К таким оценкам побуждали реальные основания. В 1848 году Еж участвовал в венгерском восстании, после чего судьба забросила его в Турцию, а позже - в Англию, где он вступил в Демократическое общество. Как агент комитета европейской демократии во время Крымской войны Еж побывал в Сербии и Болгарии, в 1863 году стал участником польского освободительного движения, после поражения которого ему предстояла судьба эмигранта. Всю свою жизнь ЕжМилковский посвятил демократической идее, которая отразилась в его произведениях (хоть иногда он не обращал достаточного внимания на художественную обработку материала). Ради этой идеи он жил, работал и призывал к этому других. Константы Войцеховский писал о нем так:

Возьмем ли в руки его «Василия Голуба» или «Историю о прапрадеде», или другое из его первых произведений, в каждом прочитаем эту мысль демократическую. Но не только народом занимался Еж в своих романах.

8 W. Bernacki, Zygmunt Fortunat Mitkowski, [w:] Wybitni polacy XIX wieku. Leksykon biograficzny, Kraków 1998, s. 244.

9 J. Klejner, W. Maciag, Zarys dziejów literatury polskiej, Wrocław 1974, s. 384. (перевод - мой, Л. Р.) 
Аристократии указывал на самолюбие, погоню за личной выгодой с унижением достоинства собственного и национального, шляхте - на расточительность и пустую жизнь, женщинам на нехватку надлежащего образования - призывал же к труду муравьиному, выносливому, к науке, к добросовестному выполнению обязанностей ${ }^{10}$.

Призывы к труду и свету науки - это жизненное и эстетическое кредо великого Каменяра. Вспомним его программное стихотворение Гімн (Вічний революичйонер - / Дух, наука, думка, воля...) или цикл Веснянки (Дай працуювать, працюювать, працуювати, / В праці сконать! или Порви пута віковї, / Що скували думку людську!/ Двигни з пітьми люд робучий).

Франко был лично знаком с Ежем (тот был корреспондентом газеты Przyjaciel ludu, которую издавал Франко вместе с Вислоухом), ему в первую очередь импонировали революционно-демократические настроения польского деятеля, его участие в борьбе за свободу народов. В письме к Михаилу Драгоманову от 7 октября 1894 года он писал:

Относительно Милковского, то действительно кацапы наврали, написав, словно это я говорил о каком-то его гетманстве на Украине и в Польше. Мы с Милковским только теперь познакомились и то виделись очень мало. Меня просил его зять Равита-Гавронский зайти к нему, но я не шел. В конце затянули меня на прощальный банкет... Там пришлось и мне сказать несколько слов в честь Ежа, и я поднес его украинское происхождение, сделал ударение на том, что он казацкое свободолюбие вынес за границы Украины и Польши, что сумел выразить симпатию к придунайским славянам и в наилучших своих повестях величал борьбу тех славян с турками, даже в такие моменты, когда его земляки с польско-державной точки зрения организовали волонтеров, чтобы помогать туркам против славян ${ }^{11}$.

Однако Франко не соглашается с некоторыми взглядами Ежа на освободительное движение украинского народа, он относит его к польским патриотам,

10 І. Франко, Зібрання творів: У 50 томах, т. 49, Київ 1980, с. 521-522.

11 І. Франко, Зібрання творів: У 50 томах, т. 47, Київ 1980, с. 192. 
которые пишут на украинском или в польских писаниях силятся дать синтезу польскости и украинофильства (Высоцкий), или, исходя от абстрактной любви к Украине, умеют согласовать с ней ненависть к украинскому национальному движению (Еж, Равита Гавронский) ${ }^{12}$.

Эта противоречивость общественно-политических взглядов Ежа отражается и в его творчестве, в частности в трилогии Бурное время.

Революционно-демократические убеждения Франко проявились в многочисленных статьях о польской литературе. Литературнокритические труды дают четкое представление о его понимании польского литературного процесса, начиная от самых давних времен и до конца XIX-нач.XX века. Франко интересовали эпохальные периоды в развитии польской литературы, ее знаковые фигуры (Адам Мицкевич, Юлиуш Словацкий, Болеслав Прус, Мария Конопницкая, Ян Каспрович), деятельность представителей украинской школь в польской литературе. Конечно, Франко прежде всего привлекала современная ему польская литература, но он осознавал, что творчество самых выдающихся польских писателей 80-90-х годов XIX века унаследовало лучшие художественные традиции предшественников. Особенно влиятельными были традиции польской литературы первой половины XIX века, литературы эпохи романтизма, потому именно к ней и были обращены взгляды Франко. Польскую романтичную литературу критик рассматривал в двух ракурсах: в ее связях с украинской литературой и с позиций освещения принципиальных для польской литературы 80-90-х гг. проблем, среди которых на первом месте была проблема реалистичного изображения жизни народа. Вопросам народности и реализма в польской литературе 80-90-х годов посвящены труды Польский крестьянин в освещении польской литературы, Современные польские поэты и Поэзия Яна Каспровича, на которой мы остановимся позже.

Сотрудничество Франко с польскими культурными деятелями, подтвержденное документально, опровергает утверждение о якобы враждовании украинского писателя со своими польскими коллегами. Подобные обвинения опровергал сам писатель:

12 І. Франко, Зібрання творів: У 50 томах, т. 27, Київ 1980, с. 259. 
Сказано обо мне, что я ненавижу польскую шляхту. Если к польской шляхте причислить Ожешко и Конопницкую, Пруса и Ленартовича, Остою и Карловича, - то такое мнение обо мне будет полностью несправедливым, потому что эту настоящую польскую шляхту, эту элиту польского народа ценю и люблю, как люблю всех благородных людей собственного и каждого другого народа. Что таким же чувством не одариваю того или другого галицкого шляхтича или и даже большую их часть, то, вероятно, по причинам полностью отличной натуры от тех, которые велят мне любить первых. Если среди галицких шляхтичей найду когда какие-либо симпатичные исключения, не мешкая, ударю о них в большой колокол ${ }^{13}$.

Франко был хорошо знаком с художественными произведениями, критическими ипублицистическимитрудами Ежа, активно полемизировал с ним относительно важных проблем литературной и общественной жизни.

В этом контексте в первую очередь следует вспомнить рецензию на дебютный сборник Яна Каспровича Поэзии, напечатанный в 1889 году во Львовском издательстве Biblioteka Mrówki с предисловием Ежа.

К Каспровичу ретроградная, юнкерско-реакционная ${ }^{14}$ критика относилась неохотно и даже настороженно, потому статья Франко о сборнике Каспровича выделялась на фоне выступлений тогдашней консервативной критики. Прежде всего Франко привлекало то, что в литературу пришел представитель трудового народа - крестьянский сын из Куяв, c демократическими взглядами ${ }^{15}$, который хорошо знал настроения и страдания простонародья. И хотя в его поэзии пробивалось то, что уже было сказано до него (возможно, ярче и решительнее), - горячий порыв к продвижению, братству и любви, без которого нет поэзии в новейшем смысле этого слова ${ }^{16}$, - молодоконсервативная пресса забила тревогу. И это было, по словам Франко,

13 І. Франко, Зібрання творів: У 50 томах, т. 31, Київ 1980, с. 32.

14 І. Франко, Зібрання творів: У 50 томах, т. 27, Київ 1980, с. 259.

15 Г. Вервес, Польська література і Украӥна, Київ 1985, с. 218.

16 І. Франко, Зібрання творів: У 50 томах, т. 27, Київ 1980, с. 259. 
инстинктивное ощущение, то таинственное дрожание, которое иногда охватывает раздраженных, холеных салонных кукол, когда в их обществе ни с того, ни с сего появится мужик - простой мужик в зипуне, в тяжелых сапогах, с грубыми руками, от которых отгоняет сильным запахом земли, что его кормит ${ }^{17}$.

Каспрович предстает в польском стихотворчестве гостем из другого мира, его поэзия преисполнена этого иного духа, который уловил Еж и выразил свое впечатление от сборника в предисловии:

Мне кажется, милый пан, что среди наших современных поэтов Вы выступаете со своим личным творческим лицом; с ярко выраженной самобытностью, с вычеканенным на Вашем челе доводом, что кастальский источник в Польше не высох ${ }^{18}$.

Франко импонирует эта меткая характеристика Каспровича, данная Ежем. Украинский писатель в основном соглашается и с такой его оценкой содержания и формы поэзии Каспровича:

В форме я заметил следы борьбы с трудностями, которые производят такое впечатление, словно вызваны умышленно; в содержании почувствовал отзвук той тоски, боли и жалоб, которые составляют сущность жизни порабощенных народов» 19 .

Однако украинский поэт считает целесообразным уточнить, что существуют разные виды неволи: политическая, экономическая и духовная.

По поводу трудностей, которые вызывали у Ежа впечатление умышленно созданных, Франко отмечает, что это действительно трудности, вызванные борьбой оригинального и сильного таланта с традицией, - чуждой ему польской и западноевропейской романтичной школой:

17 Там же, с. 260.

18 Цит. по: І. Франко, Зібрання творів: У 50 томах, т. 27, Київ 1980, с. 260.

19 Цит. по: І. Франко, Зібрання творів: У 50 томах, т. 27, Київ 1980, с. 260. 
Пан Каспрович реалист по своей природе, поэт жестокой, но здоровой действительности, в то время как традиция романтичной школы ведет его в мир призраков и франтастических фигур, утопленников, надоблачных дев, наяд и дриад, ангелов и чертей и других декоративных существ подобного сорта... эти романтичные лохмотья, которые кое-где могли еще иметь место в поэзии Словацкого, в поэзии Каспровича поражают как грубый анахронизм ${ }^{20}$.

Иван Яковлевич предостерегает Каспровича еще от одного излишества - влюбленности в абстрактную поэзию и историософские размышления (тоже рудимент традиции), что является неестественным для его стиля. Таким образом, творчество Каспровича стало для обоих критиков поводом для разговора об издержках романтизма и путях развития польского реализма.

Относительно сравнения Каспровича с Шевченко, который, по словам Ежа, черпал содержание своих произведений из того же источника, то Франко считает такое сопоставление более целесообразным, чем сравнение Шевченко с Красинским или Сырокомлей. И все же он уточняет, что главное подобие польского и украинского художников в схожести жизненных судеб, социальном происхождении:

Прежде всего имеем здесь две ягоды с того же поля, двух крестьянских сыновей, которые собственным тяжелым трудом поднялись «из серой толпы простых людей», по ступеням огромного количества страданий и унижений выкарабкались на те возвышенности, на которых, хотя и не совсем тепло и выгодно, но с которых, зато, видно широко, с которых орлиным глазом можно постигнуть далекие горизонты, распознать крутые и запутанные тропы человеческие ${ }^{21}$.

Тогда как природа, темперамент и характер их поэзии отличаются настолько, насколько отличаются сами темпераменты украинца и поляка.

20 І. Франко, Зібрання творів: У 50 томах, т. 27, Київ 1980, с. 261.

21 І. Франко, Зібрання творів: У 50 томах, т. 27, Київ 1980, с. 260. 
Франко рассуждает, а то и полемизирует с Ежем не только относительно литературных, но и злободневных социально-политических проблем. Скажем, статья Ещуе раз о галищ̧ких беспорядках появилась как попытка оперативного отзыва на статью Ежа $O$ беспорядках в Галичине. В статье Франко развивает, уточняет и оспаривает отдельные мнения польского коллеги по поводу выступлений в Галичине, при этом обращает внимание на два главных фактора, относительно которых возникла полемика, а именно: австрийское правительство с его конституцией и галицкая шляхта. Острее, чем его оппонент, Франко критикует австрийскую конституцию, которая никоим образом не ликвидирует социальное неравенство (Еж придерживался противоположного мнения), убедительно доказывая, что основной закон Австро-Венгрии сплошь капиталистический (на пользу немецкому капитализму), а избирательное право, установленное конституцией, направлено против рабочих и крестьян, на защиту интересов капиталистов и шляхты.

Существуют определенные разногласия и во взглядах обоих авторов на положение и роль галицкой шляхты. И это закономерно: Милковский как выразитель пропольских позиций излишне акцентирует внимание на притеснениях австрийского правительства и оппозиционности к нему галицкой шляхты, пытается убедить, что именно Австрия одарила Галичину иезуитамu $^{22}$. Франко решительно опровергает подобные суждения, считая утверждение об оппозиционности польской шляхты преувеличением, поскольку ее объединяют с австрийскими правительственными чиновниками классовые интересы. Поэтому шляхта без особых колебаний переходит из оппозиционного лагеря в правительственный (напоминает политическую ситуацию в Украине, когда политики активно переходят из одного лагеря в другой). По словам Франко, именно шляхта активно способствовала полонизации украинцев в Галичине, распространению здесь иезуитства. И делает вывод:

... свободы, предоставленные Галичине Австрией, действительно конституционны, но Галичина не пользуется ими только потому, что шляхта этого не хочет! 23 .

22 Цит. по: І. Франко, Зібрання творів: У 50 томах, т. 44, Київ 1980, с. 444.

23 І. Франко, Зібрання творів: У 50 томах, т. 44, Київ 1980, с. 444. 
Не будем ударяться в более подробный анализ настоящей статьи (она может стать предметом отдельного пристального внимания для историков или политологов), а лишь отметим, что отношения Ивана Франко и Теодора Ежа - интересная страница в истории украинско-польских литературных и общественных взаимоотношений, которая нуждается в скрупулезных исследованиях.

\section{Literatura}

Т. Мартиненко, Публіцистика Івана Франка у дослідженнях Ґражини Паздро, [в:] Київські полоністичні студії, редактор Р. Радишевський, т. XXIX, Київ 2017.

Г. Грабовська, Цикл рецензій на „Галицько-руську бібліографію” І. Левицького на сторінках часопису «Kurjer Lwowski», [в:] Київські полоністичні студії, редактор Р. Радишевський, т. XXIX, Київ 2017.

Г. Вервес, Іван Франко і питання українсько-польських літературногромадських взаємин, Київ 1957 //

Г. Вервес, Польська література і Україна, Київ 1985.

M. Ostrowska, T. T. Jeż (Zygmunt Miłkowski). Zycie i twórczość, Kraków 1936.

І. Франко, Зібрання творів: у 50 томах, т. 27, Київ 1980.

І. Франко, Зібрання творів: У 50 томах, т. 50, Київ 1980.

W. Bernacki, Zygmunt Fortunat Miłkowski, [w:] Wybitni polacy XIX wieku. Leksykon biograficzny, Kraków 1998.

J. Klejner, W. Maciag, Zarys dziejów literatury polskiej, Wrocław 1974, s. 384. (перевод - мой, Л. Р.)

K. Wojciechowski, Dzieje literatury polskiej, London 1943, s. 310. (перевод - мой, Л. Р.)

І. Франко, Зібрання творів: у 50 томах, т. 49, Київ 1980.

І. Франко, Зібрання творів: у 50 томах, т. 47, Київ 1980.

І. Франко, Зібрання творів: у 50 томах, т. 31, Київ 1980.

І. Франко, Зібрання творів: у 50 томах, т. 44, Київ 1980.

\section{Bibliografia}

W. Bernacki, Zygmunt Fortunat Miłkowski, [w:] Wybitni Polacy XIX wieku. Leksykon biograficzny, Kraków 1998. 
G. Grabowska, Cykl retsenzii na "Galycko-rusku bibliografiyu” I. Lewyckoho na storinkah chasopysu „Kurjer Lwowski” [w: ] „Kyivski polonistychni studii”, redaktor R. Radyshewskii, t. XXIX, Kyiv 2017.

I. Franko, Zibrannia tvoriv. U 50 tomah, t. 27, 31, 44, 47, 49, 50, Kyiv 1980.

J. Kleiner, W. Maciag, Zarys dziejów literatury polskiej, Wrocław 1974.

T. Martynenko, Publitsystyka Ivana Franka u doslidzhennyah Grazhyny Pazdro, [w:] „Kyivski polonistychni studii”, redaktor R. Radyshewskii, t. XXIX, Kyiv 2017.

M. Ostrowska, T. T. Jeż (Zygmunt Miłkowski). Życie i twórczość, Kraków 1936.

G. Verves, Ivan Franko i pytania ukraińsko-polskih literaturno-gromadskih wzayemyn, Kyiv 1957.

G. Verves, Polska literatura i Ukraina, Kyiv 1985.

K. Wojciechowski, Dzieje literatury polskiej, London 1943. 